\title{
Environmental Role in Shaping Recollection
}

\author{
Krishna Prasad Bhandari
}

\begin{abstract}
The core concern of this article is to unravel the underlying mystery of mental activities; it reveals how a writer tends to weave his thoughts and memories. The article aims at dealing with the bases of writer's reasons and recollections appeared in journal. The analysis as such becomes significant to synchronize, acknowledge and recognize the basic causes behind the seemingly scattered and deviated thoughts but coherently correlated concepts of the writer. In order to achieve such importance and objective of this study, this qualitative research has implemented an outlook-the nature / culture ambivalent aspect of the broad perspective, ecocriticism-on shaping one's perception as a tool. And the model text to be analyzed is "Reminiscences of a Journey to Greece" a journal prepared by Govinda Raj Bhattarai. After the investigation into this journal, the exploration elucidates that one's encounter with the environment becomes the generator and stimulator of mental matters-memoirs, concepts, ideas and emotions. Therefore, the key conclusion of this analysis is that one cannot generate ideas in the void or absence of context rather the external world becomes the bedrock to beget inner world - the conceptions of the creator in journal.
\end{abstract}

Keywords: Nature, culture, environment, thoughts, memories.

\section{Introduction}

Simply, environment is the surrounding where an organism exists. Etymologically, the term is taken to have originated from the French word "environ" that denotes the space surrounded in four directions (Asthana 2). Historically, "the verb environ (to surround) is of medieval provenance" and the noun, environment is the origin of the nineteenth century with the meaning, surrounded area (Buell 140). In Nepali the meaning of environment is equivalent to the sense of vātâvaran which is derived from Sanskrit's two distinct dictions: $v \bar{a} t a$ and $\bar{a} v a r a n$, which signify the 'wind' and 'covered' respectively. Thus, environment is an encircled area or an encompassed estate with air. In other words, environment refers to an air-accessible abode that gives life to the creatures. In this sense, the environment is the external condition of a creature that influences and helps for its development and makes it exist.

In a broader sense, environment entails the entities and estates touched by the air. The components contained in the coverage area of environment are physical, biological and socio- 
cultural aspects. Physical surrounding is the system of three-fold structure of lithosphere, hydrosphere and atmosphere. Biological domain of environment includes entire world of living beings found in all these three spheres-land, water and air. Biotic world is the blend of botanical and zoological aspects - the vegetation and animal world. The third wing of environment, the cultural aspect is associated with all the human-constructed paradigms concerned with economics, politics, technology, psychology and spirituality. These artificial aspects keep connection with the physical parts. The cultural concerns are imbedded in the natural entities of the environment. So, environmental study is a multi-disciplinary approach to acknowledge the influence of non biotic world on biotic and effect of culture on nature.

After 1978, from the publication of William Rueckert's essay, "Literature and Ecology: An Experiment in Ecocriticism", the issues of environment were begun to be studied under the specific -ism - the ecocriticism The literary theory has two tenets: "As a critical stance, it has one foot in literature and the other on land; as a theoretical discourse, it negotiates between the human and the non-human"(Glotfelty xix). It evaluates the literary world through the naturalistic perspective and examines the narratives and feelings of author from the environmental and ecological point of view. The critical study of the interrelationship of physical and biotic world is its broad domain. And at the same time, the study of human and natural world is its core concern; it is the prime part of the theory's discussion. In this field, the theory studies the interconnection between biological and physical world, and it also analyzes the influence of man upon nature.

In the line of affecting and being affected, at first it is argued that the culture, specifically, the cognitive aspect of human does influence the perception about the physical world. In this stream of thought, the nature writer, Barry Lopez opines that even one's idea of a geographical region is constructed by three aspects of thought: "What one knows, what one imagines and how one is disposed" (271). Human knowledge and imagination, which are the cultural products, provide the personality and recognition to the specific region. This outlook on the physical environment believes that the culturally created creativity—one's ideology, thoughts and feelings - generates the identity of the external world. Therefore, the metaphors of the particular place or the perception of the environment is embedded in the cultural background of the perceiver.

Contrary to the concept, culturally identified nature, ecocritics also argue that nature shapes one's cultural aspects particularly the cognitive side of a person. The eco-thinkers, who advocate on this stream of thought, claim that one's consciousness is constructed by the spatial and temporal aspects of the external world. Terry Gifford crediting to Synder concludes: "Consciousness, mind, imagination and language are fundamentally wild" (176). In other words, one's thoughts are guided and shaped by the wilderness or simply by the physical world. 
In the same line, Ananda Wood argues that the nature is the "animate" aspect of the universe and all the mental functions like "living actions, perceptions, thoughts and feelings...[are] taken to be the parts of nature" in philosophical and religious studies that are also the parts of culture (5:81). Viewed from this angle, the physical world is taken as the sole determiner of an individual's perceptions and procession of thought. So, one's life activities, thoughts, and knowledge are embedded in the external matters - the material world.

Such stream of argument asserts that the environmental state of a region guides and ascertains the thoughts, reasons and imagination of author in literary discourse. Glotfelty connecting the ideas with environment concludes that the "literature does not float above the material world in some aesthetic ether, but rather, plays a part in an immensely global system in which energy, nature and ideas interact (xix). Literature is not merely the expression of environmental aesthetics but it is the creative output constructed through the interaction of environment and author's ideas. Similarly, Gifford extends the interconnection of environment with poetry and narratives and stands in dualistic mode of thought with the view that "in literature nature is culture [and]. . . culture is nature" (176). Such an ambivalent attitude towards the role of nature or the culture to create the thoughts and knowledge in the literature appears to be the domain of dispute.

In order to work out this dispute, this article seeks solution in a much less noticed genrejournal. Though a journal is considered "a day-to-day record of the events in one's life, written for personal use and satisfaction, with little or no thought of publication" (Abrams and Harpham 30) like a diary, the journal is unlike to a diary. The journal is generated mostly after one's journey whereas for documenting the diary the expedition is not the essentiality. Moreover, the journal is distinct due to its specific features; it is a blend of narratives and emotions/ feelings with the commentaries of the narrator/thinker. In this sense, it is an amalgamation of the story, poem and essay - the journal writer narrates, meditates and comments. The journal having three-fold features as such is associated mostly with the travel literature about the personal experiences of author's journey in specific place and time.

A journal entails the expressions concerned with the individual insights and impressions emerged through the observation of outer world. The journal writing consists of the documentation of memories with analysis about events, places and persons. So, a journal externalizes one's inner thoughts, reactions, dreams, ideals, and sorrows about the external world. In the presentation of such issues, the thinking patterns, emotions and feelings of an individual seem to play a vital role.

However, in this process of externalizing the ideas and impressions in the journal, the presence of external world stands as the stimulator that gives expression to the mentality. One's interdependence with the varied entities of the environment is initially a fact and truth; then 
only as per this reality, one's opinions are shaped. Human beings are amidst the countless other non-human species and natural objects which stimulate human thoughts all the time; his sensual and intellectual outcomes are entangled with the physical and social environment. And in the journal too, the mental activities are guided by such environmental states and changes. Stephanie Dowrick, a theorist on journal writing opines that the outside things "are impacting on us on a moment-by-moment basis" (19) while documenting and narrating the events in journal. She asserts the journal writing is "the ceaselessly dynamic relationship between inner and outer worlds" (19). Therefore, the external images contribute to creating the internal insights and impressions in the preparation of a journal.

Based on such background, this article adopts a broad question: whether the journals can be interpreted through the ecocritical perspective or not. And if it can be, how are the narratives of journal constructed on the canvas of environment? The prime research question of this study is: how does the environmental exposure help in creating the cultural connotations of visual images in journal. To put it another way, how the narratives of physical environment are correlated with the personal interpretations of the author about the events and situations? In the interrelationship of environmental description and its metaphoric meaning, how can the physicality contribute to constructing the concept, thoughts, knowledge, insights, impressions - the totality of mentality? So, the dependency of ideas upon environmental awareness is examined in this study.

With this research question, this article aims to analyze the contribution of physical world in making the mental matters of the narrator in journal. In other words, it is to examine the role of physical setting on building up the ideas. This objective is based on the assumption that the natural world particularly the surrounding is a sole source in shaping the reason and knowledge of person; one's expressions are guided by the environment - the visible external world.

In order to address this research question, I have taken the naturalistic theory, ecocriticism as a broad perspective. As this literary criticism incorporates multiple disciplines, the dualistic outlook — nature/ culture—befits to analyze the issues raised in this article. Inside this hierarchical set, the pragmatic part-cultural domination is a cause of environmental degradation — is excluded. Only the theoretical aspect — surrounding is the sole determiner of thoughts and feelings - is a tool for the textual analysis. And the primary text is a journal prepared by Govinda Raj Bhattarai published in English for the New Millennium - a text book for B. Ed. first year prescribed by Tribhuvan University. His journal, "Reminiscences of a Journey to Greece" is on the three-day visit in one of the islands of Greece, Samos, where he spent three weeks. His journal records his day-to-day events and experiences in the surroundings of Samos from $13^{\text {th }}$ to $15^{\text {th }}$ September of 2006 . In the group of 21 , the writer was 
one of the nine Nepalese and the rest of others were Bhutanese, Greeks, a driver and two guides.

\section{Textual Analysis on "Reminiscences of a Journey to Greece"}

In the initial day of the vehicle-journey, the writer presents the panoramic scene of hills. On the bottom of a sloppy hill, tall pine trees appear. However, the forest had been engulfed in flames some four years before. He depicts the devastating scene of the forest still having "the remains of charcoal, ashes, lifeless stumps in the arid slopes" (251). The wild fire had consumed the beauty and biological beings of that part of the island. In order to preserve the sanctity and ecology of the forest, some restrictions written on the leaflets were distributed to each visitor. Such physical and social environment makes the writer call up the condition of fire consumed forests of Nepal- "I remembered how almost all of our hills and forests are engulfed by wild fire every year. But both the people and the government are unaware of it" (251. Here, the remnant of the burnt forest and strict rules for the conservation of remaining woods makes him remember more severe situation of Nepal's forests and extreme unawareness and carelessness of both the government and public sector.

Similarly, a detached dwelling from the rest of other places becomes the key source for the writer to bring the dispassionate theme / thought back. Below the burnt forest, there were other smaller islands than Samos. One of them was Icarin which was not physically connected with others; it seems as if it is standing in the mid of the ocean since time immemorial. The aloof and lonely land triggers the writer to ponder over the gloomy and indifferent mythic event (imagination). He remembers two arts made up on the human apathy: the painting of Bruegel on the downfall of ambitious Icarus, who had adopted the ambition to reach the sun and a poem created by Williams Carlos Williams entitled "Landscape with the Fall of Icarus"(251). The theme of both creations is the human indifference on the tragic end of one ambitious person. Here, the view of disconnected land lying lonely inspires the writer to reminisce the identical issue - human disinterest upon the tragedy. Thus, the disconnected land has carried out the callous, careless and unsympathetic sense in the writer's thought.

From the glimpse of remote and isolated islands, the writer thinks over the dwellers' inconvenient and problematic livelihood. In the age-old Agean Sea, a mountain, Evidelos, the highest one of that island stood. Far from the mountain, many bubbles like tiny islands were floating on the blue water. In the canvas of such physical structure, the writer thinks about the inconveniences of their entire life: "How do such islands with a population of three or four hundred manage to survive- how about their education, transportation, medicine and livelihood? How have they survived for thousands of years?" (252). The physical surroundings - the disperse small lands - also remind him the scattered remote villages and houses of Nepal where the life is still really terrible and troublesome. Here, the socio-physical 
environment of the sea locked habitats of the Greek islands provokes the writer to come up with the idea of difficult livings of landlocked rural areas of Nepal.

Likewise, in the journey to a place, Kumaradei, the clay pots and ceramic goods help the writer to commemorate the ancient art of Greece. Kumaradei, located on a hill is enriched with the open display of artistic "earthen ware and special ceramic objects like cups, pots flower vases, big jars, small gift items, decorative pieces and keepsakes" (253). They were kept for sale under the green shady grapevines with ripening grapes. Such alluring and exquisite environment blended in both artificial and natural aspects helps the writer recall the hand-made pots of Nepal, and man-and-machine prepared pottery of Greece. For the structures and shapes of the ceramic cups, the Greeks credited to Pythagoras and they identified the cups as the Pythagorean cups. This fact drags the writer five decades back when he had learnt the theorem of Pythagoras for his SLC exam. So, seeing the ripe grapes, the writer concentrates on the perfect art designed and created under the theory of Pythagoras. And at the same time, the pots kept under "cool shade of vineyard" (253) makes him ponder over the ancient Greek art preserved in this cool country; and the Greek pottery and Pythagoras cups become the bases to remind him Nepal's pottery occupation and his late school life.

While travelling down the slope of a hill, the writer heard the clamor of sea that reminded him the theme of revolt reported by the guide, Irin. As the group went ahead "along the slope, the roaring sound of the sea could be heard in the late afternoon from far away" (253). The islanders had inhabited there in small numbers covering large areas. The uproar of the sea inspires the writer to write the identical social issues. According to the guide, the traditional norms and values were being defeated. The young generation revolted against the ancient out dated cultures and customs. In order to shift to the modernity, the mass media performed the significant role. Its regular reminding and instructive voice contributed a lot to make the youths conscious. Consequently, the young people of these islands shifted to other cities deserting their dwellings - the villages. In the same context, he adds another revolting theme - the Modern Greek feminists' rebellious voice and activities of disobedience to so called established patriarchal systems that they gradually began to discard. Such issues related with rebellion are written owing to the roaring sound of the sea.

Furthermore, the olive trees and fruits of the slopes and Samos become the resources to remind him of the identical vegetation and fruit of Scotland and Nepal respectively. While he was passing through the unique wild woods spread all over the slopes, he saw mostly the "short bushy trees with grayish-silver leaves. The branches hung downwards like the thin branches of a weeping willow" (254). In fact, they were the olive trees that resembled a berry tree but are shorter than the oak plants. Such greenery of Greece helps him to draw the similar scene of Scotland: "I remember the silver birches of Scotland" (254). Similarly, during his stay in 
Samos, he savored varieties of olive dishes from breakfasts to dinners. The taste of olive meals makes him nostalgic: "In size it [the olive fruit] is small like bayer or jamuna fruit. Today Nepali bajaar also sells expensive olive oil" (254). Here, the green olive trees of the outdoor environment triggers him to remember his previous visit of Scotland and the indoor surrounding of dining table full of olive items takes him to his native land, where bayer and jamuna are still considered the forest fruits.

In the late afternoon of second day visit, the observation of a museum reminds the writer of a museum-like personality of Nepal, Manujbabu Mishra. The museum was located in the capital city of Samos, Bathi. The city "museum was full of historic objects dating back to 600 BC" (255). There one could see ancient art, emperors, queens, gods, goddesses and renowned Greek citizens of bygone days. Such preservation of great people, primitive art and culture, and divinities in the premises of four walls in a foreign land becomes the medium of his memory about Manujbabu Mishra. In fact, Mishra was a prominent painter, a veteran artist, and prolific writer of art, culture, fiction and history. About his contribution, Bhattarai briefly writes: "He had introduced to us Greece-Roman Hellenic,Byzantine and Egyptian Gods and men and drawn a fine distinction among the arts of every period" (255), Here, the images of Greek art, culture and custom kept in the museum makes the writer ponder over the legendry artist, Mishra, who contributed a lot to flourish and foster Nepali culture of culture/ heritage of colors in words. Now, Mishra is no more; he passed away in 2018, twelve years after Bhattarai associated him with the museum of Samos in his journal.

After two-day visit in Samos, when the writer with his friends landed in Athens International Airport, he remembered the tragedy occurred in Nepal and mankind's misery composed in a poem of Mathew Arnold. Athens is known as the cradle of ancient Greek culture and civilization. The historical city is recognized as the origin place of tragic drama. Although he did not watch any tragedies on the theatre, mere his presence in Athens makes him think over the tragic occurrences. At first he recollected the originators of tragedy: "The world honors Sophocles, Euripides, and Aeschylus, the great masters of tragedy, who were born in Athens" (256). Here, the land and air of Athens created the environment for him to commemorate the creators of tragedies. This thought further drags him in his country, where the peace-agreement between the then-government and Maoists was accomplished; however politically people were not quite assured and socially unsafe - the ten-year rebellion had been just landed. After he contemplated on Nepali comrade's commitment of peace, instantly he remembered the first stanza of the poem, Dover Beach, composed by Mathew Arnold. The poem is about human tragedy and misery. Thus, mere the presence of one in certain surroundings, one can have the waves and webs of thoughts, reasons, emotions and ideas about the events that occurred in past and continue till present. 
At the end of his visit, he covered historically huge heritage sites hurriedly that environs him to esteem the prominent poetic personality - the great poet Laxmi Prasad Devkota. The journal writer visited Acropolis where the stone statues and deities had still preserved the primitive Greek art. The visit of Syntagma Square "reminded of syntagmatic and paradigmatic pair that Saussure used" in language structure (257). The writer also inspected the Theatre of Dionysus, the great natural stone stage constructed for the performance of Greek tragic dramas. Having visited such heritage sites of Greek art and culture, he recollected the contribution of Devkota to the country: "While I had a glance at the long vista of ancient Greek city that stretched below the Acropolis, standing on the top of Acropolis, Mahakavi Devkota came to my mind" (258). Bhattarai honors Devkota as the first poet to introduce Greek myths in Nepali literature through his epics. Thus, here, the cultural environment loaded with historical significance becomes the base for him to remind the incomparable contribution of Devkota to Nepali literary world and his remarkable position in poetry.

\section{Conclusion}

The ecocritical insight on the journal of Bhattarai suggests that the environmental exposure experienced or seen in specific place and time while journeying becomes the key source in generating and shaping reasons, thoughts and feelings. This brief analysis also indicates that one's cultural aspect does not contribute much to create concept specifically in journal. In the

journal, Bhattarai's memories are determined and shaped according to the inherent nature of the Nature - the environment. In other words, in accordance with the underlying feature of the physical environment, his ideas and memories appear. Therefore, in the journal the totality of environment - the spatial, temporal and social setting - predominantly becomes the prime source to procreate the perceptions, reasons and knowledge. One can adopt this perspective to perceive and interpret other genres of literature, namely narratives and meditative ones as well.

\section{Works Cited}

Abrams, M.H. and Geoffrey Galt Harpham. A Glossary of Literary Terms. 11th ed. Cengage Learning, 2015.

Asthana, Madhu. Environment: A Brief Study. Motilal Banarsidas, 2008.

Bhattarai, Govinda Raj. "Reminiscences of a Journey to Greece". English for the New Millennium. Eds. Jai Raj Awasthi, Govinda Raj Bhattarai and Vishnu Singh Rai. Ekta Books, 2015, pp. 249-58.

Buell, Lawrence. The Future of Environmental Criticism: Environmental Crisis and Literary Imagination. Blackwell Publishing Ltd., 2005. 
JODEM: Journal of Language and Literature, vol. 10, no. 1, issue 12, 2019/2076BS

Dowrick, Stephanie. Creative Journal Writing: The Art and Heart of Reflection. Wise Angels, 2007.

Gifford,,Terry. "The Social Construction of Nature." The Green Studies Reader: From Romanticism to Ecocriticism. Ed. Lawrence Coup. Routledge, 2012, pp. 173-76.

Glotfelty, Cheryll. Introduction. The Ecocriticism Reader. Eds. Cheryll Glotfelty and Harold Fromm. U of Georgia, 1996. pp. xv-xxxvii.

Lopez, Barry. Arctic Dreams: Imagination and Desire in a Northern Landscape. Bantam Books, 1987.

Wood, Ananda. "Nature and Life: Old Ideas, New Questioning." Man in Nature, edited by Bidyanath Saraswati, pp. 79-102. Prakr $\square t i$ : The Integral Vision, general editor, Kapila Vatsyayan, vols. 5, D. K. Printworld, 1995. 